Check for updates

Cite this: RSC Adv., 2019, 9, 31867

Received 13th August 2019

DOI: 10.1039/c9ra06293a

rsc.li/rsc-advances
Accepted 27th September 2019

\section{Synthesis and application of amine-containing conjugated small molecules for the automatic formation of an electron transporting layer via spontaneous phase separation from the bulk- heterojunction layer $\uparrow$}

\author{
Juae Kim, $t^{a}$ Yong Ryun Kim, $\ddagger^{b}$ Minji Kim, ${ }^{a}$ Jong Sung Jin, ${ }^{c}$ Ji Yeong Sung, ${ }^{c}$

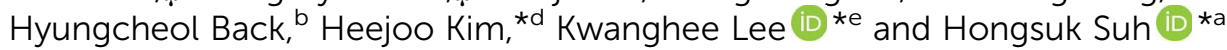

\begin{abstract}
Carbazole-based conjugated small molecule electrolytes (CSEs) containing different numbers of amine groups were synthesized and applied to bulk-heterojunction $(\mathrm{BHJ})$ organic solar cells for the formation of a spontaneous self-assembled electron transporting layer (ETL). The active layer was spin-coated with a mixture solution containing the $\mathrm{BHJ}$ materials and a small amount of $\mathrm{CSE}$, and a thin layer of CSE was formed underneath the active layer (CSE/BHJ bi-layer) via spontaneous phase separation, which is confirmed by the depth profile of the time of flight secondary ion mass spectroscopy (ToF-SIMS) spectrum. The amino groups in the CSEs form hydrogen-bonds with the surface of indium tin oxide (ITO), which acts as an ETL in BHJ solar cells. Moreover, the formed CSE layer is capable of changing the effective work function (WF) of ITO. An increasing number of amino groups in the CSEs (from Cz1N to $\mathrm{Cz} 3 \mathrm{~N}$ ) provides more reduction of the effective WF of ITO, which results in a lower internal resistance and a higher power conversion efficiency (PCE). Furthermore, the enhanced hydrogen bonding between the amines and ITO with an increased number of amine groups has been studied by XPS. This result suggests that one-step processing provides a reduction of the manufacturing cost, which can provide an attractive design concept for ETL fabrication.
\end{abstract}

\section{Introduction}

Over the past decade, bulk-heterojunction (BHJ) solar cells comprising conjugated polymer donors and fullerene acceptors have attained significant attention due to their advantages, such as solution processability, large area fabrication, and applicability for roll-to-roll processes. ${ }^{1-4}$ The improvement of the power conversion efficiency (PCE) of BHJ solar cells has been achieved through several strategies, such as control of BHJ morphology, new molecular design of the semiconducting

${ }^{a}$ Department of Chemistry, Chemistry Institute for Functional Materials, Pusan National University, Busan 609-735, Republic of Korea. E-mail: hssuh@pusan.ac.kr ${ }^{b}$ Research Institute for Solar and Sustainable Energies, Gwangju Institute of Science and Technology, Gwangju 61005, Republic of Korea

'Busan Center, Korea Basic Science Institute (KBSI), Busan 46742, Republic of Korea ${ }^{d}$ Institute of Integrated Technology, Gwangju Institute of Science and Technology, Gwangju 61005, Republic of Korea. E-mail: heejook@gist.ac.kr

${ }^{e}$ School of Materials Science and Engineering, Gwangju Institute of Science and Technology, Gwangju 61005, Republic of Korea. E-mail: klee@gist.ac.kr

$\dagger$ Electronic supplementary information (ESI) available: DSC and TGA curves, electrochemical characteristics, XRD powder patterns, device performance, solubility studies, and ${ }^{1} \mathrm{H}$ and ${ }^{13} \mathrm{C}$ NMR spectra. See DOI: 10.1039/c9ra06293a

$\ddagger$ Contributed equally to this work. materials, and modification of the interfaces. ${ }^{5-12}$ Among them, introduction of interlayer materials between the indium tin oxide (ITO) bottom electrode and the photoactive layer in an inverted BHJ solar cell is regarded as one of the facile and efficient methods of improving the PCE of BHJ solar cells. ${ }^{13-16}$ The introduced layer can generate an interfacial dipole at the interface to change the WF of the electrode, leading to ohmic contact between the BHJ layer and ITO. As a result, the electron transfer from the photoactive layer to the ITO electrode is facilitated, increasing the PCE. ${ }^{13,15,17}$

Solution processable metal oxides such as $\mathrm{ZnO}^{18}$ and $\mathrm{TiO}_{2}$ ref. 19 and ${ }^{20}$ are the most popular electron transport layer (ETL) materials. However, their complicated fabrication method, with the application of a high annealing temperature $\left(>200^{\circ} \mathrm{C}\right)$ for the crystallization of the metal oxides, is not compatible with roll-to-roll manufacturing processes for high throughput. ${ }^{18,21}$ To solve this problem, there is an alternative route without thermal annealing that is afforded by a $\mathrm{ZnO}$ nanoparticle (ZnO NP) emulsion, which allows applications in roll-to-roll deposition. ${ }^{22,23}$ However, this sequential process for fabricating the ETL/BHJ bi-layered structure increases the number of fabrication steps for multi-layered devices, and thus is also unfavorable for the mass production of $\mathrm{BHJ}$ solar cells. As a low temperature processable ETL, polyelectrolytes such as 
poly[(9,9-bis(3'-(N,N-dimethylamino)propyl)-2,7-fluorene)-alt-2,7(9,9-dioctylfluorene)] (PFN) ${ }^{24}$ and polyethyleneimine ethoxylated (PEIE) ${ }^{25}$ have been shown to be alternative candidates. Furthermore, their electronic structure can be easily tailored for ohmic contact at the interface by changing the polymer backbone or side chains. ${ }^{26-35}$ However, polyelectrolytes/BHJ bi-layer structures are also fabricated with a sequential process.

Recently, Lee et al. reported a one-step process for fabricating an ETL/BHJ bi-layered structure, which is enabled by using a mixed BHJ solution including a small amount of nonconjugated polyethyleneimine (PEI). The amines in the PEI could induce spontaneous phase migration to ITO during the spin-casting due to the hydrogen bonding between PEI and ITO, thereby forming an ETL/BHJ bi-layered structure simply by using one spin-casting process. ${ }^{36-38}$ Subsequently, a dipole layer is formed between the migrated PEI molecules and the surface of ITO, resulting in similar device performance to that of sequentially processed devices. However, as observed in the sequentially processed bi-layered devices, the optimized thickness of the PEI layer for the one-step processed BHJ solar cells was less than $5 \mathrm{~nm} .{ }^{39}$ Because the backbone of PEI is an insulating material causing thickness sensitivity, a thicker PEI layer $(>5 \mathrm{~nm})$ causes poor charge transport, decreasing both FF and JSC significantly. This result can be ascribed to a lack of conjugation portion in the polymer backbone of PEI. ${ }^{40-43}$ Recently, Kim et al. reported self-organization of polymer additive poly(2-vinylpyridine) (P2VP) via one-step solution processing to increase the device performance. But P2VP was used in addition to a metal oxide ( $\mathrm{ZnO}$ ) layer, and could not reduce the processing steps of the device. ${ }^{44}$ In contrast to the aforementioned works, Cao et al. reported a good device performance with a thicker ETL (thickness $\sim 40 \mathrm{~nm}$ )/BHJ bi-layered structure when they used a conjugated polyelectrolyte (CPE) as the ETL. ${ }^{45}$ Although this bi-layered structure was fabricated by a sequential process, this result implies that CPEs comprising a conjugated portion and hydrophilic amine groups made it possible to keep the charge transport property.

Here, we report the design, syntheses and properties of novel conjugated small molecule electrolytes (CSEs), which have not only a conjugated portion for efficient electron transport but also amine groups, essential functional group of PEI for spontaneous phase separation. These CSEs with a carbazole moiety and amine groups have a simple synthetic method, batch-tobatch reproducibility, a well-defined molecule structure and absolutely fixed molecular weight. Carbazole was used as the conjugated moiety because it has been widely utilized as an ETL material. The hydrophobic carbazole portion will provide reasonable solubility of the CSEs in the solvent that is being used for the spin-coating of one solution of electron donor/ electron acceptor/CSE. The amine groups provide the driving force for spontaneous phase separation to form a CSE layer on top of ITO.

Furthermore, we systemically studied the spontaneous phase separation of $\mathbf{C z x N}$ as an ETL in inverted organic solar cells by using one spin-coating method using one solution of PTB7-Th/PC ${ }_{71} \mathrm{BM} / \mathbf{C z x N}$. With the aim of achieving better device performance, we chose to vary the number of amines to provide
Cz1N, Cz2N, and Cz3N, since the variation of the number of amine groups can improve the hydrophilicity of the CSE. Furthermore, Kelvin probe (KP) measurement was used to check how the number of amines varies the WF of ITO cathodes. In addition to this, the hydrogen bonding between the amine and ITO after spontaneous phase separation has been confirmed by XPS.

The KP measurements on CzxN/ITO showed that the WF of ITO decreased on increasing the number of amine groups. The water contact angle measurements on $\mathbf{C z x N}$ and BHJ : $\mathbf{C z x N}$ films showed that the hydrophilic properties of CSEs were improved on increasing the number of amine groups in the CSEs. A higher performance was obtained with the device with an increased number of amine groups (Cz3N), which provided a lower WF of ITO, lower water contact angle and more efficient hydrogen bonding with ITO as confirmed by XPS. Therefore, our results will provide a way of developing effective ETL materials inducing spontaneous phase separation to realize a printing process of large area $\mathrm{BHJ}$ solar cells with reduced steps.

\section{Results and discussion}

\section{Material characterization}

The general synthetic routes toward the intermediates and small molecules are outlined in scheme 1. The detail synthetic routes are described in the experimental section and the ESI. $\dagger$ 9-(6-Bromo-hexyl)-9H-carbazole (2) was synthesized by alkylation of $9 H$-carbazole (1). Cz1N was prepared by amination of compound 2 . After the Kornblum oxidation of compound 2, 6-carbazol-9-yl-hexanal (3) was obtained. Cz2N and Cz3N were synthesized by reductive amination of the aldehyde with a carbazole moiety using the corresponding amine-containing reagents. All of the final compounds, which have simple synthetic routes and can be easily purified, dissolve in polar solvents such as $\mathrm{MeOH}$. The clear identifications of the synthesized molecules were performed by using ${ }^{1} \mathrm{H}$ NMR, ${ }^{13} \mathrm{C}$ NMR and mass spectrometry as shown in the ESI, Fig. S1-S3.†

The UV-vis absorption spectra of the solutions (in $\mathrm{MeOH}$ ) and solid films of CzxNs are presented in Fig. $S 4 \uparrow$ and the $\lambda_{\max }$ values both for solutions and solid films are summarized in Table S1. $\dagger$ As shown in Fig. S4(a), $\dagger$ the solutions of CzxNs in $\mathrm{MeOH}$ exhibited almost identical absorption spectra with peaks at $330 \mathrm{~nm}$ and $345 \mathrm{~nm}$. In solid films, the wavelength of the optical absorption onset was slightly red-shifted from $356 \mathrm{~nm}$ to $358 \mathrm{~nm}$ on increasing the number of amine groups. Therefore, the optical band gaps for $\mathbf{C z 1 N}$, Cz2N, and $\mathbf{C z 3 N}$ were estimated to be $3.48,3.47$ and $3.46 \mathrm{eV}$, respectively. Nevertheless, the shapes of the absorption spectra for all solid films were almost identical, indicating that the change of the side chains does not disturb the electronic structure of the carbazole moiety. The electrochemical properties of the $\mathbf{C z x N}$ molecules, such as the highest occupied molecular orbital (HOMO) and lowest unoccupied molecular orbital (LUMO) energy levels, were characterized by using cyclic voltammetry (CV) (see Fig. S5 $\uparrow$ and Table S2 $\dagger$ ). The HOMO and LUMO energy levels of Cz1N, Cz2N and Cz3N were estimated to be $-6.99,-7.03,-7.04 \mathrm{eV}$ and -3.19 , 

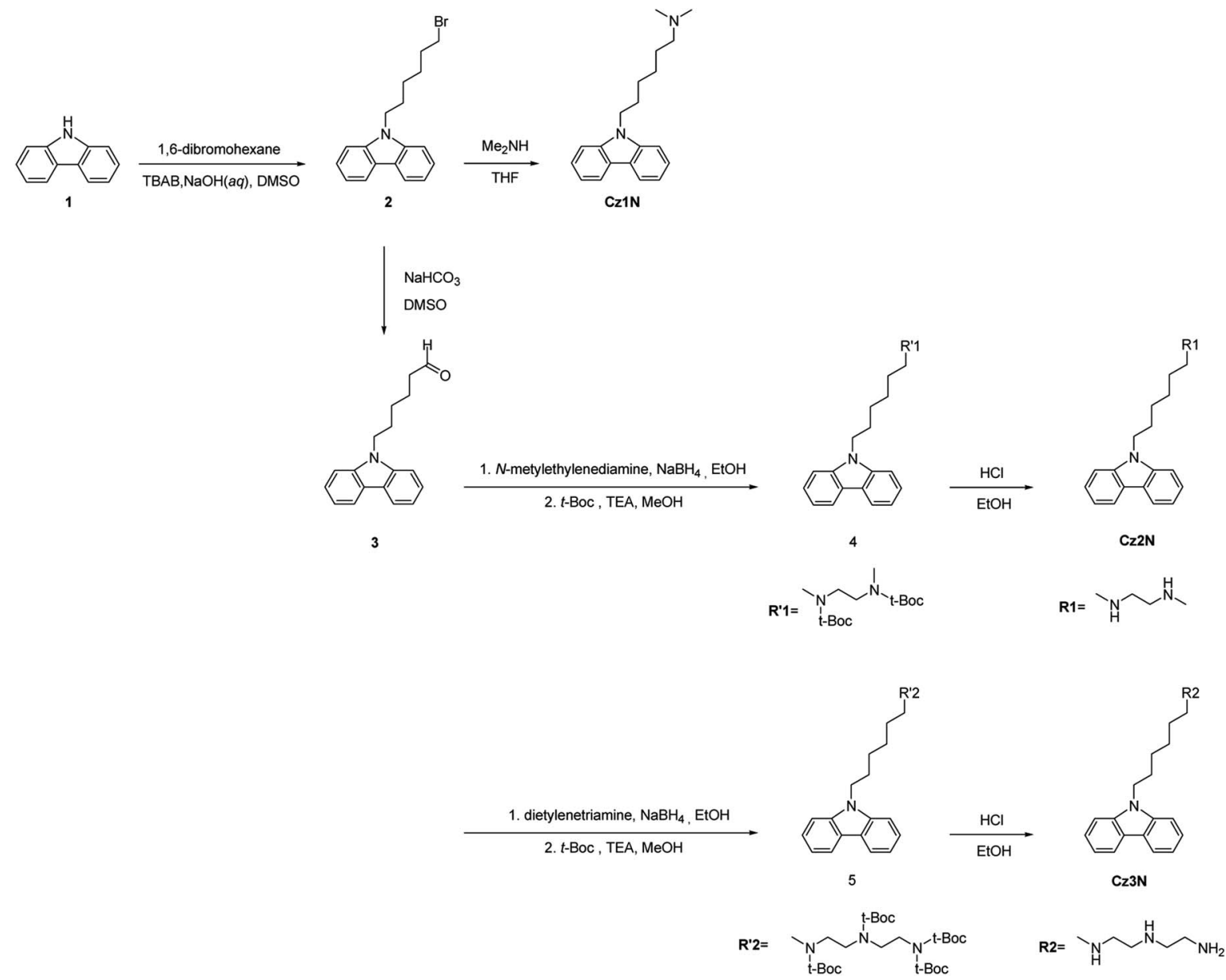

Scheme 1 Synthetic routes for the small molecules.

$-3.05,-3.04 \mathrm{eV}$, respectively. The estimated band gaps of $\mathbf{C z 1 N}$, $\mathbf{C z 2 N}$, and Cz3N were $3.80,3.98$, and $4.00 \mathrm{eV}$, respectively. Although the band gaps of each material from the optical absorption spectra and CV measurements were marginally different, typically it is accepted that there is a difference between the optical band gap and electrochemical band gap of organic materials. ${ }^{\mathbf{4 6 , 4 7}}$ As observed in the absorption spectra of solid films, the difference of the HOMO for each material was also very small (see Fig. S5† and Table $\mathrm{S} 2 \dagger$ ).

\section{Device characterization}

Fig. 1(a) illustrates the single-step fabrication method of the BHJ/CzxN layer on an ITO substrate, and Fig. 1(b) exhibits the chemical structures of the electron donor, poly([2,6'-4,8-di(5ethylhexylthienyl)benzo[1,2-b;3,3-b]dithiophene $]\{3$-fluoro-2[(2ethylhexyl)carbonyl]thieno[3,4-b]thiophenediyl\}) (PTB7-Th), electron acceptor, phenyl- $\mathrm{C}_{71}$ butyric acid methyl ester $\left(\mathrm{PC}_{71} \mathrm{BM}\right)$, and electron transporting materials, Cz1N, Cz2N and $\mathbf{C z 3 N}$, used in this study. Inverted $\mathrm{BHJ}$ organic solar cells were prepared with the configuration of ITO/PTB7-Th: $\mathrm{PC}_{71^{-}}$ $\mathrm{BM}: \mathbf{C z x N} / \mathrm{MoO}_{x} / \mathrm{Ag}$, in which the $\mathbf{C z x N}$ layer with a different number of amine groups (1 to 3 ) was introduced, via spontaneous phase separation, to examine the effect on the device performance. To clarify the function of CzxNs in the BHJ solar cells, we also fabricated the reference device: ITO/PTB7Th : $\mathrm{PC}_{71} \mathrm{BM} / \mathrm{MoO}_{x} / \mathrm{Ag}$. Fig. 2(a) exhibits the current densityvoltage $(J-V)$ characteristic curves of devices containing different CzxNs, and the corresponding device performances are summarized in Table 1. The device without $\mathbf{C z x N}$ yielded an average PCE of less than $1 \%$ with an extremely low $V_{\text {OC }}$ of $0.13 \mathrm{~V}$. This low $V_{\mathrm{OC}}$ value can be ascribed to the high-energy barrier between the LUMO value of $\mathrm{PC}_{71} \mathrm{BM}$ and the work function of ITO, which hinders the formation of ohmic contact at the interface. Interestingly, on adding a small amount of CzxNs, including $\mathbf{C z 1} \mathbf{N}, \mathbf{C z 2 N}$, and $\mathbf{C z 3 N}$, the PCE is increased from $0.24 \%$ to $4.91 \%$. (For the best champion device, the PCE increased from $0.53 \%$ to $5.67 \%$ ). This is attributed to the formation of an ETL, which induces a substantially decreased WF of ITO via the development of interfacial dipoles and reduces the energy barrier between the $\mathrm{BHJ}$ and ITO substrate as shown in Fig. 2(b). Additionally, we also performed impedance spectroscopy exhibiting a significantly decreased internal resistance on increasing the number of amine groups in the CzxNs: Cz3N $(145 \Omega)<\mathbf{C z 2 N}(158 \mathrm{k} \Omega)<\mathbf{C z 1 N}(200 \mathrm{k} \Omega)$ as shown in Fig. 2(d). Typically, a reduced internal resistance in BHJ solar 
(a)

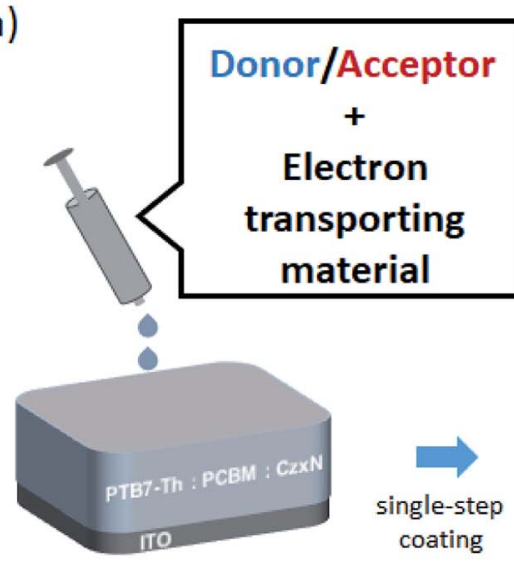

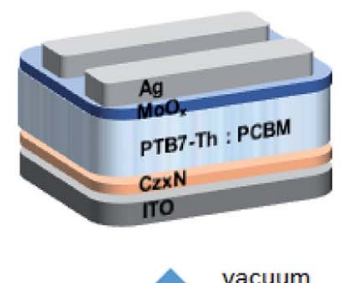

deposition

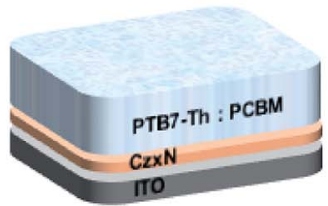

(b)

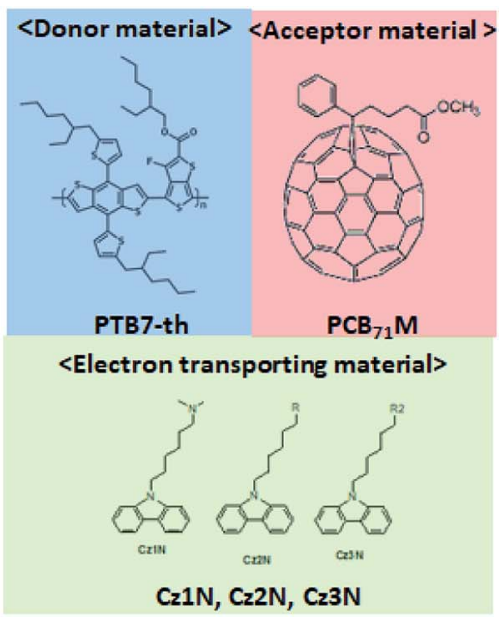

Fig. 1 (a) Schematic diagram of the single-step process for fabricating a BHJ layer, including vacuum deposition on an ITO substrate. (b) Chemical structure of the electron donor, acceptor and electron transporting layer used in this study.

cells can be ascribed to a decrease of the bulk resistance of $\mathrm{BHJ}$ films or a decrease of the series resistance at the interface between the ETL and active layers. The bulk resistance of BHJ films is also significantly related to the change of surface morphology of the BHJ films. Therefore, we observed the surface morphology of the $\mathbf{C z x N}$ : BHJ films by using the (a)

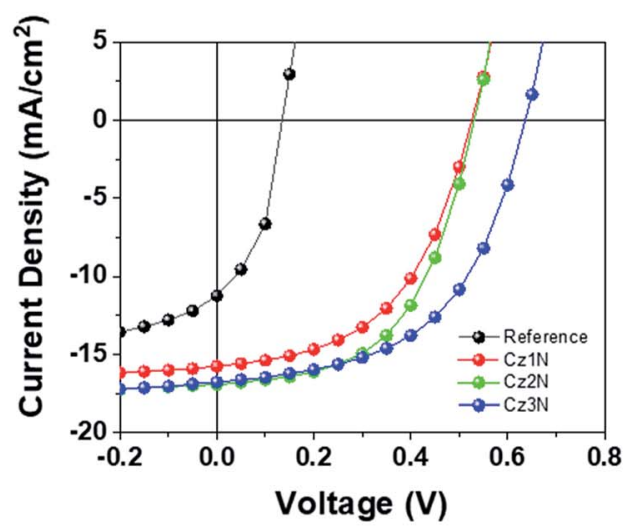

(c)

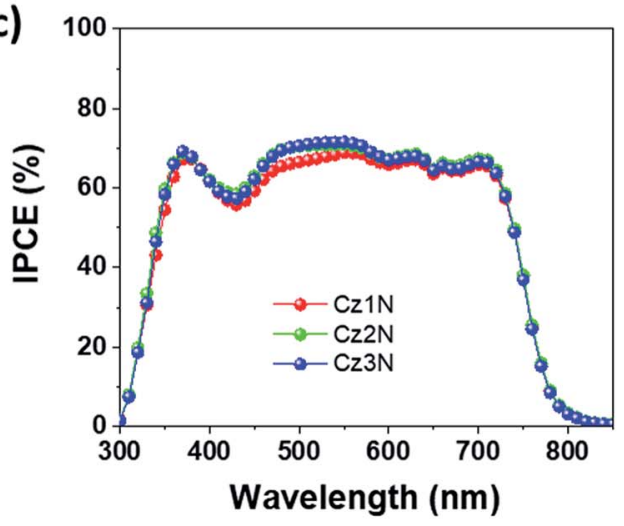

(b)

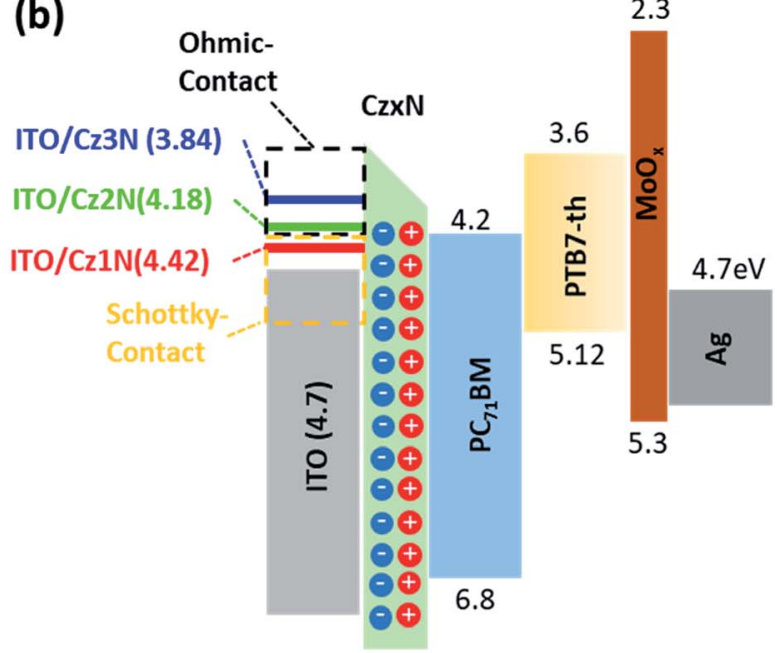

ITO/CzxN/PCBM:PTB7-th/MoOx/Ag

(d)

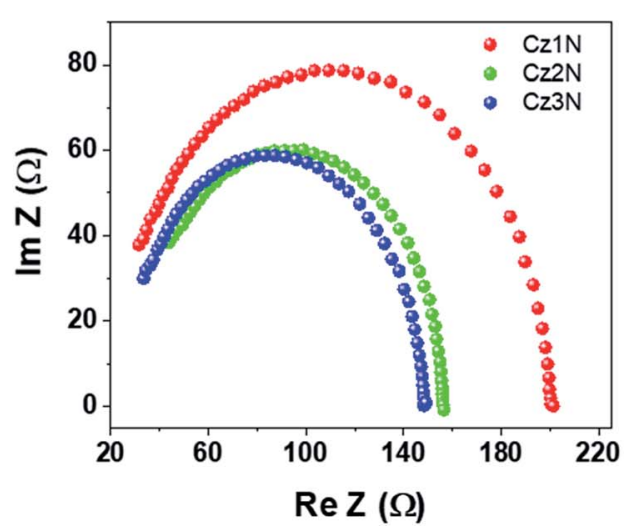

Fig. 2 (a) Current density-voltage ( $J-V$ characteristic curves, (b) energy level diagram, (c) the Incident Photon-to-Electron Conversion Efficiency (IPCE) spectra and (d) Nyquist plots of the devices from the impedance spectroscopy of the devices with different conjugated small molecules containing a number of amine groups from 1 to 3 (Resistance (Re Z), Impedance (Im Z)). 
Table 1 Photovoltaic properties of the CzxNs : BHJ blend based solar cells. The mean values of each parameter $\left(V_{\mathrm{oc}}, J_{\mathrm{sc}}, \mathrm{FF}\right.$, and $\left.\mathrm{PCE}\right)$ with the standard deviation were calculated on the basis of 20 devices

\begin{tabular}{llcccc}
\hline Interlayer & $V_{\mathrm{OC}}(\mathrm{V})$ & $J_{\mathrm{SC}}\left(\mathrm{mA} \mathrm{cm}^{-2}\right)$ & $\mathrm{FF}(\%)$ & PCE $(\%)$ & $J_{\mathrm{SC}}{ }^{a}\left(\mathrm{~mA} \mathrm{~cm}^{-2}\right)_{\mathrm{IPCE}}$ \\
\hline None & $0.13 \pm 0.04$ & $6.70 \pm 0.60$ & $0.28 \pm 0.02$ & $0.24 \pm 0.12$ & \\
Cz1N & $0.50 \pm 0.01$ & $14.90 \pm 0.52$ & $0.48 \pm 0.02$ & $3.81 \pm 0.37$ & 14.00 \\
Cz2N & $0.55 \pm 0.07$ & $15.10 \pm 0.86$ & $0.51 \pm 0.05$ & $4.21 \pm 0.41$ & 16.05 \\
Cz3N & $0.60 \pm 0.04$ & $15.50 \pm 0.89$ & $0.53 \pm 0.02$ & $4.91 \pm 0.35$
\end{tabular}

${ }^{a}$ is integrated $J_{\mathrm{SC}}$ from the IPCE spectra.

tapping mode of atomic force microscopy (AFM). As shown in Fig. S6(a)-(c), $\dagger$ despite slightly different surface morphologies, it can be noticed that the small grains in the $\mathrm{BHJ}$ films were almost similar in the AFM images. This result is well consistent with the trend of $J_{\mathrm{SC}}$ values obtained in the $J-V$ characteristics (small change of $J_{\mathrm{SC}}$ value from $\mathbf{C z 1 N}$ to $\mathbf{C z 3 N}$, see Table 1); the surface morphology of the BHJ films is not significantly influenced by changing the number of amine groups on the CSEs. With this result and KP measurements for CzxNs, it can be concluded that the effect of the interface is more dominant for the decrease of the resistance in the device. Therefore, the charge recombination in the $\mathbf{C z x N}$ : $\mathrm{BHJ}$ devices is reduced. Even though the best PCE values of PTB7-Th/PC ${ }_{71} \mathrm{BM}$ with the standard ETL system are higher than our resulting data, our method has the merit of eliminating one of the processing steps. So, this type of material, for the formation of an ETL by using spontaneous phase separation, should be consistently researched, especially for roll-to-roll processes. The photovoltaic properties of the PTB7-Th-based BHJ solar cells with a standard ETL are included in the ESI. $\dagger$

\section{Mechanism}

In order to gain an insight into the formation of the vertically selfassembled ETL of CzxNs via a single-step coating process, we investigated the location of the $\mathbf{C z x N}$ layer in the ITO/CzxN : BHJ structure using time-of-flight secondary-ion mass spectroscopy (ToF-SIMS), which allowed the distribution of the composition along the depth of the film to be detected. Fig. 3(a)-(c) exhibit the ToF-SIMS depth profiles of the ITO/CzxN : BHJ structure. Each material, including ITO, CzxN and PTB7-Th, has been tracked (a)

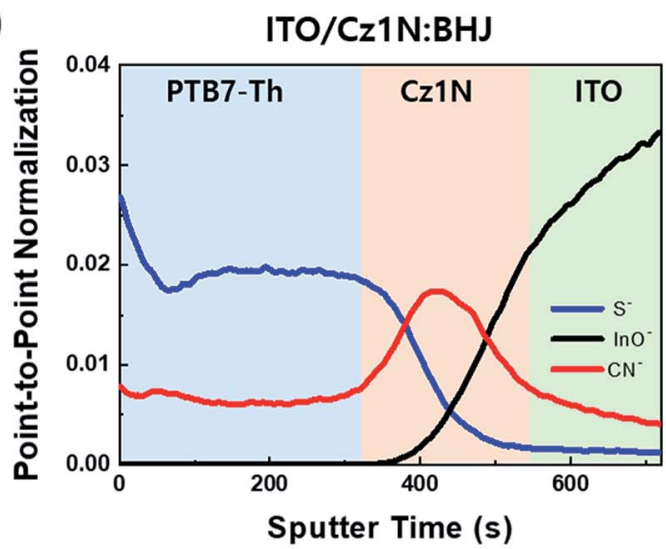

(b)

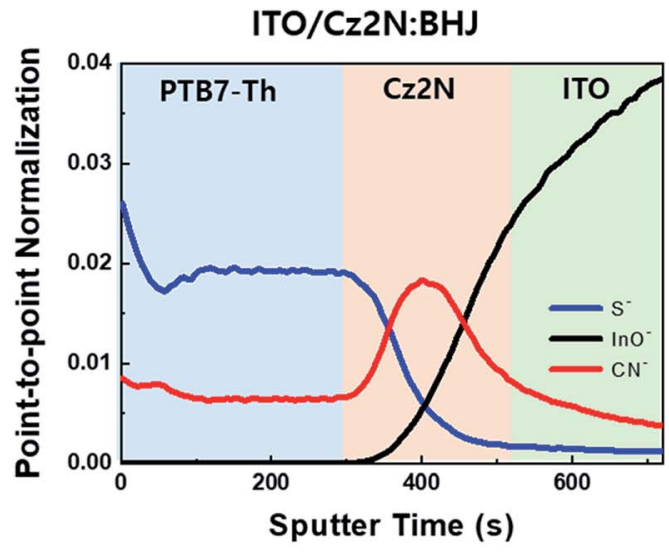

(c)

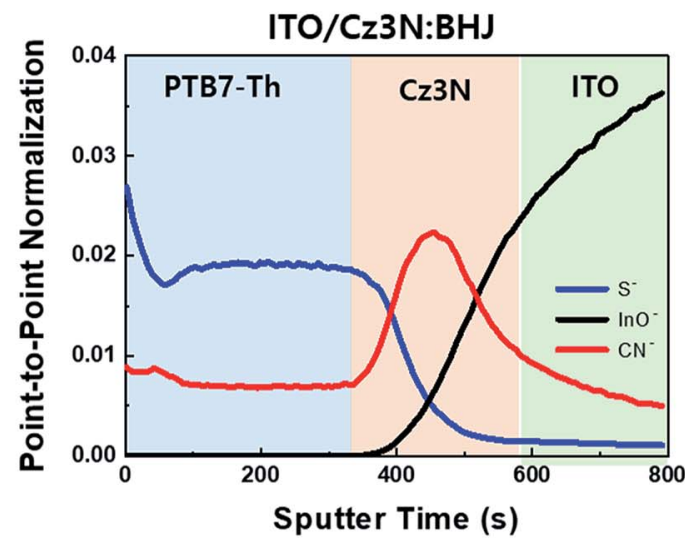

Fig. 3 ToF-SIMS depth profiles for (a) ITO/Cz1N : BHJ, (b) ITO/Cz2N : BHJ and (c) ITO/Cz3N : BHJ. 
(a)

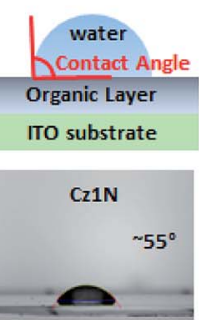

Cz1N:PTB7-th/PCBM

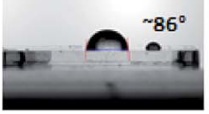

(b)

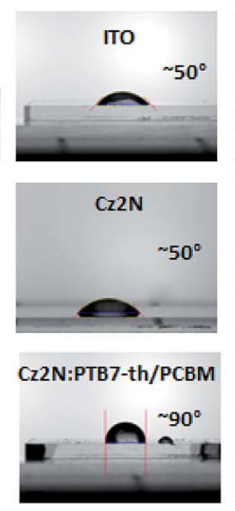

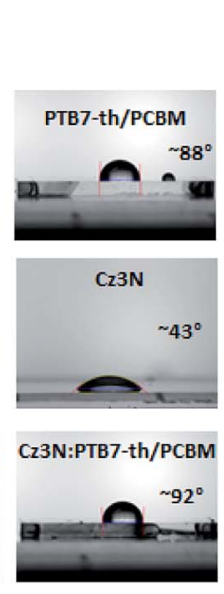

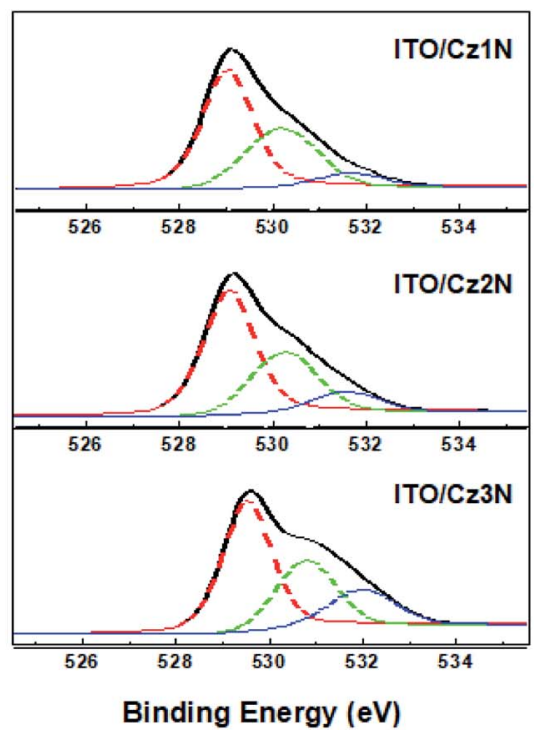

(c)

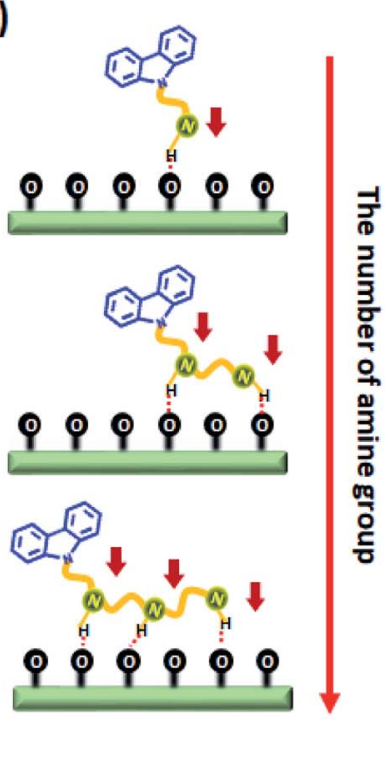

Fig. 4 (a) Water contact angle measurement, (b) high-resolution XPS deconvoluted spectra of O 1s for ITO/CzxNs and (c) the concept of spontaneous phase separation of conjugated small molecules.

down with their unique ions. The $\mathrm{S}^{-}$and $\mathrm{InO}^{-}$are assigned to the PTB7-Th and ITO, respectively, and the $\mathrm{CN}^{-}$ion is attributed to the existence of CzxNs. The accumulation of $\mathrm{CN}^{-}$ions, with high intensity, at the interface between the ITO and $\mathrm{BHJ}$ layer was monitored, which shows the formation of the $\mathbf{C z x N}$ layer by spontaneous vertical phase separation during the single-step coating process of the $\mathbf{C z x N}$ : BHJ blend solutions. This phenomenon of spontaneous vertical phase separation may be attributed to the high surface energies of the $\mathbf{C z x N s}$ relative to the BHJ components. Therefore, these results show that the introduction of CzxNs, which have a conjugated portion and amine groups in one molecules, in a one-step process has the advantage of reduction of the processing steps.

To support the formation of a $\mathbf{C z x N}$ self-assembled layer on top of the ITO substrate and the absence of $\mathbf{C z x N}$ in the selfassembled $\mathrm{BHJ}$ layer, water contact angle measurements of the samples (described in methods) have been carried out. Fig. 4(a) shows snapshots of a water droplet on the bare ITO substrate, BHJ film, CzxN films and CzxN : BHJ films on ITO, respectively. From this data, it can be concluded that the hydrophilic property of the films increased with the increase of the number of amine groups $\left(\mathbf{C z 1 N}<\mathbf{C z 2 N}<\mathbf{C z 3 N}, 55^{\circ}>50^{\circ}>\right.$ $43^{\circ}$ ), whereas the $\mathbf{C z x N}: \mathrm{BHJ}$ films show strong hydrophobic properties with the increase of the number of amine groups $\left(\mathbf{C z 3 N}: \mathrm{BHJ}>\mathbf{C z 2 N}: \mathrm{BHJ}>\mathbf{C z 1 N}: \mathrm{BHJ}, 92^{\circ}>90^{\circ}>86^{\circ}\right)$. This is because of not only the presence of amine groups in the CzxNs, which lead to hydrophilicity, but also the non-polar chemical composition from the $\mathrm{BHJ}$ materials having hydrophobicity. We also note that the hydrophobicity of the $\mathbf{C z x N}: \mathbf{B H J}$ films is relatively similar to that of the $\mathrm{BHJ}$ film itself. That is, the uppermost surface contains no CzxNs, indicating that the vertical self-assembly process for the $\mathrm{BHJ} / \mathbf{C z x N}$ bi-layered structure occurred during film formation (Table 2).

To understand the interaction between the CzxNs and ITO substrate during the single-coating process, we carried out X-ray photoelectron spectroscopy (XPS) measurements on the three

Table 2 Deconvolution results of XPS spectra of the ITO/CzxNs

\begin{tabular}{|c|c|c|c|c|c|c|}
\hline Interlayer & Position (eV) & $\begin{array}{l}\% \text { Relative } \\
\text { intensity }\end{array}$ & FWHM (eV) & $\mathrm{GL}^{a}(\%)$ & Area (P) CPS $(\mathrm{eV})$ & Assignment \\
\hline \multirow[t]{3}{*}{ Cz1N } & 529.63 & 58.63 & 1.17 & 41 & 124139 & In-O \\
\hline & 530.68 & 34.31 & 1.64 & 0 & 72642 & $\mathrm{Sn}-\mathrm{O}$ \\
\hline & 532.03 & 7.07 & 1.51 & 0 & 14962 & $\mathrm{O}-\mathrm{H}, \mathrm{O}-\mathrm{C}$ and $\left(\mathrm{O}_{2}\right)^{2-}$ \\
\hline \multirow[t]{3}{*}{$\mathrm{Cz} 2 \mathrm{~N}$} & 529.68 & 58.14 & 1.18 & 36 & 80434 & $\mathrm{In}-\mathrm{O}$ \\
\hline & 530.76 & 31.24 & 1.52 & 2 & 43222 & $\mathrm{Sn}-\mathrm{O}$ \\
\hline & 531.93 & 9.77 & 1.48 & 0 & 13522 & $\mathrm{O}-\mathrm{H}, \mathrm{O}-\mathrm{C}$ and $\left(\mathrm{O}_{2}\right)^{2-}$ \\
\hline \multirow[t]{3}{*}{ Cz3N } & 529.49 & 54.17 & 1.24 & 34 & 51857 & In-O \\
\hline & 530.75 & 28.83 & 1.50 & 0 & 27597 & $\mathrm{Sn}-\mathrm{O}$ \\
\hline & 531.94 & 17.00 & 1.67 & 0 & 16279 & $\mathrm{O}-\mathrm{H}, \mathrm{O}-\mathrm{C}$ and $\left(\mathrm{O}_{2}\right)^{2-}$ \\
\hline
\end{tabular}

${ }^{a}$ GL: \% Lorentzian-Gaussian. 
different $\mathbf{C z x N}$ layers (Cz1N, Cz2N and $\mathbf{C z 3 N}) /$ ITO substrates. As shown in Fig. 4(b), the $\mathrm{O}$ 1s core level XPS spectra are presented as solid lines, while the deconvolutions of the $\mathrm{O}$ 1s spectra with Gaussian peaks are presented as dashed lines. The O 1 s core level signals were successfully fitted to three peaks corresponding to the In-O $(\mathrm{BE}=529.5 \mathrm{eV}), \mathrm{Sn}-\mathrm{O}(\mathrm{BE}=530.7 \mathrm{eV})$ and chemically adsorbed $\mathrm{O}-\mathrm{H}$ bonding $(\mathrm{BE}=531.9 \mathrm{eV})$, respectively. ${ }^{48-51}$ As compared to $\mathbf{C z 1 N}$ and $\mathbf{C z 2 N}$, Cz3N exhibited higher intensity of the peak at $531.9 \mathrm{eV}$ corresponding to the chemically adsorbed $\mathrm{O}-\mathrm{H}$ bonds, indicating that the increase of the number of amine groups effectively provides more chemically adsorbed $\mathrm{O}-\mathrm{H}$ bonds, which implies that the interfacial interaction between the amine groups and the ITO was increased. The CzxNs have protons attached to the electro-negative nitrogen atoms, which work as the hydrogen bonding donors toward the electronegative oxygen atoms, which work as the hydrogen bonding acceptors, at the surface of ITO.

\section{Conclusions}

We designed and synthesized carbazole-based CSEs, Cz1N, Cz2N and $\mathbf{C z 3 N}$, with different numbers of amine groups, by reductive amination reaction to achieve the spontaneous phase separation of the amine-containing CSEs for the automatic formation of an ETL layer, out of one solution containing the bulk-heterojunction materials and CSEs. A strong interfacial dipole caused by the hydrogen bonding between the amine groups of the small molecules and ITO is formed at the interface of ITO/CzxNs, leading to a decrease of the effective WF of ITO. Cz3N showed the lowest WF of ITO and series resistance at the interface caused by more hydrogen bonding interaction with ITO as confirmed by XPS.

Spontaneous phase separation generated the automatic formation of the bulk-heterojunction layer and electron transporting $\mathbf{C z x N}$ interlayer when one solution containing $\mathbf{C z x N}$ and $\mathrm{BHJ}$ materials was spin-casted on ITO, which was verified by performing ToF-SIMS elemental depth profiles. When the number of amine groups was increased, the device performance was enhanced caused by more effective spontaneous phase separation, and lower WF of ITO and impedance. It was demonstrated that increasing the number of amine groups in the CSEs (from $\mathbf{C z 1 N}$ to $\mathbf{C z 3 N}$ ) enhanced the hydrogen bonding between the CzxNs and ITO, as confirmed by XPS, and provides higher PCE. These results show that the introduction of CzxNs in one-step processing by using spontaneous phase separation has the advantage of enabling the reduction of the processing steps. By optimizing the structure of the CSE via the introduction of a more efficient electron transporting conjugated moiety and modification of the side chain, it could be possible to realize a more practical procedure for device fabrication.

\section{Experimental section}

\section{Materials}

All reagents were purchased from Aldrich or TCI, and used without further purification. ${ }^{1} \mathrm{H} /{ }^{13} \mathrm{C} \mathrm{NMR}$ spectra were recorded by a Varian Gemini-300 spectrometer (recorded in ppm units). High resolution mass spectra (HRMS) were recorded on a JEOL
JMS-700 mass spectrometer under electron impact (EI) or fast atom bombardment (FAB) conditions at the Korea Basic Science Institute (Daegu).

\section{Synthesis of monomers and small molecules}

9-(6-Bromo-hexyl)-9H-carbazole (2). To a mixture of $9 \mathrm{H}^{-}$ carbazole (1) (5 g, $29.9 \mathrm{mmol})$, tetrabutylammonium bromide (TBAB) (cat.) and a solution of $\mathrm{NaOH}(6.0 \mathrm{~g}, 149.5 \mathrm{mmol}$, in $10 \mathrm{ml}$ of $\mathrm{H}_{2} \mathrm{O}$ ) in $100 \mathrm{ml}$ of dimethyl sulfoxide (DMSO) was added 1,6-dibromohexane $(3.7 \mathrm{ml}, 23.9 \mathrm{mmol})$ at $40{ }^{\circ} \mathrm{C}$. After completion of the addition, the reaction mixture was stirred for $10 \mathrm{~min}$ at $40{ }^{\circ} \mathrm{C}$. After pouring into $100 \mathrm{ml}$ of $\mathrm{H}_{2} \mathrm{O}$, the reaction mixture was extracted with $2 \times 100 \mathrm{ml}$ of $\mathrm{CHCl}_{3}$. The combined organic phase was washed with $3 \times 100 \mathrm{ml}$ of water. The organic phase was concentrated under reduced pressure and purified by flash column chromatography to give $3.8 \mathrm{~g}(38 \%)$ of compound 2 as a white solid. ${ }^{1} \mathrm{H}$ NMR (300 $\left.\mathrm{MHz}, \mathrm{CDCl}_{3}\right)$ : $\delta(\mathrm{ppm}) 8.13(\mathrm{~d}, 2 \mathrm{H}, J=7.7 \mathrm{~Hz}) 7.49(\mathrm{t}, 2 \mathrm{H}, J=7.7 \mathrm{~Hz}) 7.42$ (d, $2 \mathrm{H}, J=8.2 \mathrm{~Hz}) 7.25(\mathrm{t}, 2 \mathrm{H}, J=7.6 \mathrm{~Hz}) 4.32(\mathrm{t}, 2 \mathrm{H}, J=7.0 \mathrm{~Hz}) 3.37$ $(\mathrm{t}, 2 \mathrm{H}, J=7.0 \mathrm{~Hz}) 1.91(\mathrm{qi}, 2 \mathrm{H}, J=7.6 \mathrm{~Hz}) 1.83$ (qi, 2H, $J=7.6$ $\mathrm{Hz})$ 1.55-1.35 (m, 4H); ${ }^{13} \mathrm{C}$ NMR (75 $\left.\mathrm{MHz}, \mathrm{CDCl}_{3}\right): \delta$ (ppm) 140.42 , 125.70, 122.86, 120.46, 118.85, 108.68, 42.87, 33.92, 32.62, 28.88, 27.98, 26.51. HRMS $\left(\mathrm{m} / z, \mathrm{EI}^{+}\right)$calcd for $\mathrm{C}_{18} \mathrm{H}_{20} \mathrm{BrN}$, 329.0779 , found 329.0776 .

6-Carbazol-9-yl-hexanal (3). To a solution of $\mathrm{NaHCO}_{3}(5 \mathrm{~g}$, $10.2 \mathrm{mmol}$ ) in $10 \mathrm{ml}$ of dimethyl sulfoxide (DMSO) was added compound $2(2 \mathrm{~g}, 6.0 \mathrm{mmol})$ at $120^{\circ} \mathrm{C}$. The reaction mixture was stirred for $30 \mathrm{~min}$ at $120{ }^{\circ} \mathrm{C}$. After pouring into $100 \mathrm{ml}$ of $\mathrm{H}_{2} \mathrm{O}$, the reaction mixture was extracted with $2 \times 100 \mathrm{ml}$ of ethyl acetate. The combined organic phase was washed with $3 \times$ $100 \mathrm{ml}$ of water. The combined organic phase was concentrated under reduced pressure and purified by flash column chromatography to give $0.6 \mathrm{~g}(33 \%)$ of compound 3 as a white solid. ${ }^{1} \mathrm{H}$ NMR (300 MHz, $\left.\mathrm{CDCl}_{3}\right): \delta(\mathrm{ppm}) 9.72(\mathrm{~s}, 1 \mathrm{H}) 8.11(\mathrm{~d}, 2 \mathrm{H}, J=7.7$ $\mathrm{Hz}) 7.47(\mathrm{t}, 2 \mathrm{H}, J=7.7 \mathrm{~Hz}) 7.39(\mathrm{~d}, 2 \mathrm{H}, J=8.3 \mathrm{~Hz}) 7.23(\mathrm{t}, 2 \mathrm{H}, J=$ $7.7 \mathrm{~Hz}) 4.31(\mathrm{t}, 2 \mathrm{H}, J=7.1 \mathrm{~Hz}) 2.39(\mathrm{t}, 2 \mathrm{H}, J=7.0 \mathrm{~Hz}) 1.91(\mathrm{t}, 2 \mathrm{H}$, $J=7.7 \mathrm{H}) 1.65(\mathrm{t}, 2 \mathrm{H}, J=7.6 \mathrm{H}) 1.50-1.35(\mathrm{~m}, 2 \mathrm{H}) ;{ }^{13} \mathrm{C} \mathrm{NMR}(75$ $\left.\mathrm{MHz}, \mathrm{CDCl}_{3}\right): \delta$ (ppm) 202.36, 140.33, 125.65, 122.80, 120.40, 118.82 , 108.59, 43.70, 42.75, 28.82, 26.80, 21.76. HRMS $(\mathrm{m} / \mathrm{z}$, $\mathrm{FAB}^{+}$) calcd for $\mathrm{C}_{18} \mathrm{H}_{20} \mathrm{NO}, 266.1545$, found 266.1541.

\{2-[tert-Butoxycarbonyl-(6-carbazol-9-yl-hexyl)-amino]-ethyl\}methyl-carbamic acid tert-butyl ester (4). A solution of compound $3(3.0 \mathrm{~g}, 9.1 \mathrm{mmol})$ and $N$-methylethylenediamine $(0.78 \mathrm{ml}, 9.1 \mathrm{mmol})$ in $20 \mathrm{ml}$ of EtOH was stirred at $50^{\circ} \mathrm{C}$ for $5 \mathrm{~h}$. Then, the reaction mixture was treated with $\mathrm{NaBH}_{4}(0.3 \mathrm{~g}, 9.1$ $\mathrm{mmol}$ ) and stirred overnight. After treating under reduced pressure to remove EtOH, the reaction mixture was extracted with $2 \times 100 \mathrm{ml}$ of ethyl acetate. The combined organic phase was washed with $3 \times 50 \mathrm{ml}$ of water. The organic phase was concentrated under reduced pressure. The crude product was treated with $3 \mathrm{ml}$ of triethylamine and $25 \mathrm{ml}$ of $\mathrm{MeOH}$. After cooling to $0{ }^{\circ} \mathrm{C}$, the reaction mixture was treated with di-tertbutyl dicarbonate $(39.7 \mathrm{ml}, 185.5 \mathrm{mmol})$ in $10 \mathrm{ml}$ of $\mathrm{MeOH}$ and stirred for $1 \mathrm{~h}$. After warming to room temperature, the mixture was stirred overnight. The reaction mixture was extracted with 2 $\times 50 \mathrm{ml}$ of $\mathrm{CHCl}_{3}$. The combined organic phase was washed 
with $3 \times 50 \mathrm{ml}$ of water. The organic phase was purified by flash column chromatography to give $3.0 \mathrm{~g}$ (29\%) of compound 4 as a white oil. ${ }^{1} \mathrm{H}$ NMR (300 MHz, $\left.\mathrm{CDCl}_{3}\right): \delta(\mathrm{ppm}) 8.12(\mathrm{~d}, 2 \mathrm{H}, J=$ $7.7 \mathrm{~Hz}) 7.47(\mathrm{t}, 2 \mathrm{H}, J=7.6 \mathrm{~Hz}) 7.41(\mathrm{~d}, 2 \mathrm{H}, J=8.2 \mathrm{~Hz}) 7.23(\mathrm{t}, 2 \mathrm{H}$, $J=7.1 \mathrm{~Hz}) 4.31(\mathrm{t}, 2 \mathrm{H}, J=7.1 \mathrm{~Hz}) 3.64(\mathrm{t}, 2 \mathrm{H}, J=7.7 \mathrm{~Hz}) 2.48(\mathrm{t}$, $2 \mathrm{H}, J=7.7 \mathrm{~Hz}) 2.33(\mathrm{t}, 2 \mathrm{H}, J=7.7 \mathrm{~Hz}) 2.24(\mathrm{~s}, 3 \mathrm{H}) 1.95-1.85(\mathrm{~m}$, 2H) 1.48 (s, 18H) 1.45-1.30 (m, 6H); $\left.{ }^{13} \mathrm{C} \mathrm{NMR} \mathrm{(75} \mathrm{MHz,} \mathrm{CDCl}_{3}\right)$ : $\delta(\mathrm{ppm})$ 152.44, 140.39, 125.57122 .77 120.32, 118.70, 108.66, 82.13, 57.85, 55.54, 43.87, 42.98, 42.58, 28.99 28.07, 27.37, 27.29, 27.17. HRMS $\left(\mathrm{m} / z, \mathrm{EI}^{+}\right)$calcd for $\mathrm{C}_{31} \mathrm{H}_{45} \mathrm{~N}_{3} \mathrm{O}_{4}, 523.3410$, found 523.3412 .

[2-(2,2'-Di-tert-butoxycarbonyl-ethylamino)-ethyl]-(6-carbazol-9yl-hexyl)-carbamic acid tert-butyl ester (5). The reaction mixture was reacted under the same conditions as compound $\mathbf{4}$ and the crude product was purified by flash column chromatography to give $2.2 \mathrm{~g}(16 \%)$ of compound 5 as a white oil. ${ }^{1} \mathrm{H}$ NMR $(300 \mathrm{MHz}$, $\left.\mathrm{CDCl}_{3}\right): \delta(\mathrm{ppm}) 8.09(\mathrm{~d}, 2 \mathrm{H}, J=7.6 \mathrm{~Hz}) 7.45(\mathrm{t}, 2 \mathrm{H}, J=7.6 \mathrm{~Hz}) 7.38$ $(\mathrm{d}, 2 \mathrm{H}, J=7.6 \mathrm{~Hz}) 7.22(\mathrm{t}, 2 \mathrm{H}, J=7.6 \mathrm{~Hz}) 4.29(\mathrm{t}, 2 \mathrm{H}, J=7.0 \mathrm{~Hz})$ 3.45-3.05 (m, 10H) 2.05-1.85 (m, 2H) 1.42 (s, 36H) 1.35-1.20 (m, $6 \mathrm{H}) ;{ }^{13} \mathrm{C}$ NMR (75 MHz, $\left.\mathrm{CDCl}_{3}\right): \delta$ (ppm) 156.08, 155.26, 140.37, 125.57, 122.80, 120.32, 118.71, 108.59, 80.09, 79.48, 79.07, 47.68, 47.30, 46.72, 45.82, 45.26, 44.83, 42.94, 39.65, 39.47, 28.98, 28.38, 28.12, 27.10, 26.62. HRMS $\left(m / z, \mathrm{FAB}^{+}\right) \mathrm{C}_{42} \mathrm{H}_{65} \mathrm{~N}_{4} \mathrm{O}_{8}, 753.4802$, found 753.4799 .

(6-Carbazol-9-yl-hexyl)-dimethyl-amine (Cz1N). A solution of compound 2 ( $2.0 \mathrm{~g}, 6.0 \mathrm{mmol})$ in $20 \mathrm{ml}$ of tetrahydrofuran (THF) was treated with dimethylamine $(30.2 \mathrm{ml}, 60.6 \mathrm{mmol})$ at $-78{ }^{\circ} \mathrm{C}$ and the mixture was stirred for 2 days under Ar. After pouring into $30 \mathrm{ml}$ of $\mathrm{NaOH}(0.1 \mathrm{M})$, the reaction mixture was extracted with $2 \times 50 \mathrm{ml}$ of ethyl acetate. The combined organic phase was washed with $3 \times 50 \mathrm{ml}$ of water. The organic phase was concentrated under reduced pressure and purified by flash column chromatography to give $0.4 \mathrm{~g}(25 \%)$ of $\mathbf{C z 1 N}$ as a bright yellow oil. ${ }^{1} \mathrm{H}$ NMR $\left(300 \mathrm{MHz}, \mathrm{CDCl}_{3}\right): \delta(\mathrm{ppm}) 8.14(\mathrm{~d}, 2 \mathrm{H}, J=$ $7.7 \mathrm{~Hz}) 7.49(\mathrm{t}, 2 \mathrm{H}, J=7.7 \mathrm{~Hz}) 7.42(\mathrm{~d}, 2 \mathrm{H}, J=7.7 \mathrm{~Hz}) 7.26(\mathrm{t}, 2 \mathrm{H}$, $J=7.7 \mathrm{~Hz}) 4.30(\mathrm{t}, 2 \mathrm{H}, J=7.1 \mathrm{~Hz}) 2.30-2.20(\mathrm{~m}, 2 \mathrm{H}), 2.21(\mathrm{~s}, 6 \mathrm{H})$ 1.92-1.85 (qi, $2 \mathrm{H}, J=7.7 \mathrm{~Hz}$ ) 1.52-1.30 (m, 6H); ${ }^{13} \mathrm{C}$ NMR (125 $\left.\mathrm{MHz}, \mathrm{CDCl}_{3}\right) \delta(\mathrm{ppm}) 140.41,125.56,122.80,120.32,118.70$, 108.63, 59.69, 45.43, 42.99, 28.92, 27.54, 27.25, 27.24. HRMS (m/ $z, \mathrm{FAB}^{+}$) calcd for $\mathrm{C}_{20} \mathrm{H}_{27} \mathrm{~N}_{2}, 295.2174$, found 295.2177.

$\boldsymbol{N}$-(6-Carbazol-9-yl-hexyl)- $\boldsymbol{N}^{\prime}$-methyl-ethane-1,2-diamine (Cz2N). To a solution of compound $4(1.8 \mathrm{~g}, 3.4 \mathrm{mmol})$ in $30 \mathrm{ml}$ of EtOH was added $4 \mathrm{~N} \mathrm{HCl}(55 \mathrm{ml}, 220.0 \mathrm{mmol})$ dropwise at $0{ }^{\circ} \mathrm{C}$. After stirring at room temperature overnight, the reaction mixture was treated with saturated $\mathrm{NaOH}(\mathrm{aq})$ to adjust the $\mathrm{pH}$ to around 11. After extraction of the reaction mixture with $2 \times 100 \mathrm{ml}$ of ethyl acetate, the combined organic phase was washed with $3 \times 100 \mathrm{ml}$ of water. The organic phase was concentrated under reduced pressure to give $0.4 \mathrm{~g}(24 \%)$ of $\mathbf{C z 2 N}$ as a yellow oil. ${ }^{1} \mathrm{H}$ NMR (300 $\mathrm{MHz}, \mathrm{CDCl}_{3}$ ): $\delta(\mathrm{ppm}) 8.11(\mathrm{~d}, 2 \mathrm{H}, J=7.6 \mathrm{~Hz}) 7.47(\mathrm{t}, 2 \mathrm{H}, J=7.7 \mathrm{~Hz}) 7.41(\mathrm{~d}, 2 \mathrm{H}, J$ $=7.7 \mathrm{~Hz}) 7.23(\mathrm{t}, 2 \mathrm{H}, J=7.7 \mathrm{~Hz}) 4.31(\mathrm{t}, 2 \mathrm{H}, J=7.0 \mathrm{~Hz}) 2.72(\mathrm{t}, 2 \mathrm{H}, J$ $=5.9 \mathrm{~Hz}) 2.35(\mathrm{t}, 2 \mathrm{H}, J=5.8 \mathrm{~Hz}) 2.28(\mathrm{t}, 2 \mathrm{H}, J=7.0 \mathrm{~Hz}) 2.20-2.05(\mathrm{~m}$, 2H) 2.16 (s, 3H) 1.95-1.80 (m, 2H) 1.55-1.30 (m, 6H); ${ }^{13} \mathrm{C}$ NMR (75 $\left.\mathrm{MHz}, \mathrm{CDCl}_{3}\right): \delta(\mathrm{ppm}) 140.41,125.55,122.80,120.31,118.70,108.62$, 60.52 , 57.86, 43.00, 42.18, 39.56, 28.96, 27.25, 27.22, 27.15. HRMS $\left(\mathrm{m} / \mathrm{z}, \mathrm{FAB}^{+}\right)$calcd for $\mathrm{C}_{21} \mathrm{H}_{30} \mathrm{~N}_{3}, 324.2440$, found 324.2437.
[2-(2-Amino-ethylamino)-ethyl]-(6-carbazol-9-yl-hexyl)-amine (Cz3N). The same conditions as for $\mathbf{C z 2 N}$ were used to give $0.2 \mathrm{~g}$ $(42 \%)$ of $\mathbf{C z 3 N}$ as a yellow oil. ${ }^{1} \mathrm{H}$ NMR (300 $\left.\mathrm{MHz}, \mathrm{CDCl}_{3}\right)$ : $\delta(\mathrm{ppm}) 8.09$ (d, 2H, $J=7.7 \mathrm{~Hz}) 7.45(\mathrm{t}, 2 \mathrm{H}, J=7.0 \mathrm{~Hz}) 7.38(\mathrm{~d}$, $2 \mathrm{H}, J=7.6 \mathrm{~Hz}) 7.21(\mathrm{t}, 2 \mathrm{H}, J=7.7 \mathrm{~Hz}) 4.29(\mathrm{t}, 2 \mathrm{H}, J=7.1 \mathrm{~Hz}) 2.77$ $(\mathrm{t}, 2 \mathrm{H}, J=5.7 \mathrm{~Hz}) 2.75-2.60(\mathrm{~m}, 4 \mathrm{H}) 2.54(\mathrm{t}, 2 \mathrm{H}, J=6.4 \mathrm{~Hz}) 1.85-$ $1.60(\mathrm{~m}, 2 \mathrm{H})$ 1.55-1.45 (m, 8H); ${ }^{13} \mathrm{C}$ NMR (150 MHz, $\mathrm{CDCl}_{3}$ ): $\delta(\mathrm{ppm}) 140.36,125.56,122.74,120.33,118.68,108.63,52.46$, 49.84, 49.49, 49.26, 42.98, 41.75, 29.97, 28.95, 27.25, 27.15. HRMS $\left(m / z, \mathrm{FAB}^{+}\right)$calcd for $\mathrm{C}_{22} \mathrm{H}_{33} \mathrm{~N}_{4}, 353.2705$, found 353.2702 .

\section{Device fabrication and characterization}

Solution preparation. The $\mathbf{C z x} \mathbf{N}$ solutions were diluted in methanol to $0.2,0.1$ and $0.05 \mathrm{wt} \%$. The blend solution of PTB7Th : $\mathrm{PC}_{71} \mathrm{BM}$ was prepared by dissolving $7 \mathrm{mg}$ of PTB7-Th and $10.5 \mathrm{mg}$ of $\mathrm{PC}_{71} \mathrm{BM}$ (1: 1.5 by weight) in $1 \mathrm{ml}$ of chlorobenzene (CB) with a 1,8-diiodooctane (DIO) additive ( $3 \%$ by volume) and stirred overnight at $60{ }^{\circ} \mathrm{C}$. The $\mathbf{C z x N}$ : BHJ solutions were prepared by mixing $\mathbf{C z x N}$ and the blend solutions (1:9 by volume).

Device fabrication. Inverted OPV (i-OPV) devices were fabricated with the structures of indium tin oxide (ITO) glass/ $\mathbf{C z x N}: \mathrm{BHJ} / \mathrm{MoO}_{x} / \mathrm{Ag}$ or $\mathrm{ITO} / \mathrm{BHJ} / \mathrm{MoO}_{x} / \mathrm{Ag}$. The coated ITO substrates were ultra-sonicated with deionized water, acetone and IPA for 20 minutes each, and then dried overnight in an oven at $85{ }^{\circ} \mathrm{C}$. The ultra-sonicated ITO glass substrates were UVOzone treated for 20 minutes prior to device fabrication. For the i-OPV structures, the $\mathbf{C z x N}$ : $\mathrm{BHJ}$ or $\mathrm{BHJ}$ were spin-cast onto the ITO at $800 \mathrm{rpm}$ for 30 seconds, followed by $5000 \mathrm{rpm}$ for 10 seconds. Finally, $\mathrm{MoO}_{x}(2 \mathrm{~nm})$ and $\mathrm{Ag}(120 \mathrm{~nm})$ layers were deposited on the blend films via thermal evaporation under a high vacuum of $1 \times 10^{-6}$ torr with a shadow mask. The active area of the devices was defined by the patterned $\mathrm{Ag}$ electrode $\left(0.0464 \mathrm{~cm}^{2}\right)$.

Characterization. The performance of the solar cells, current $J-V$ characteristics, was calibrated (with a $100 \mathrm{~ms}$ delay) using a Keithley 238 source measure unit (Keithley Instruments, Inc) under AM 1.5G (air mass 1.5G global) illumination with $100 \mathrm{~mW}$ $\mathrm{cm}^{-2}$ intensity (Newport, Class AAA solar simulator) without a UV filter. Moreover, the external quantum efficiency (EQE) spectra were measured using a solar cell spectral response QE/ IPCE measurement system (PV measurements, Inc.). The IPCE measurements were performed without bias light. The impedance spectroscopy measurements of the OPVs were obtained using a galvanostat mode (PGSTAT30) under the same illumination conditions as for the calibration of the OPVs. The atomic force microscopy (AFM) images were obtained with a scanning probe microscope system (n-Tracer SPM, NanoFocus Inc.). ToFSIMS experiments were performed with a ToF-SIMS 5 (ION-ToF $\mathrm{GmbH}$, Münster, Germany) in the KBSI Busan Center by using a pulsed $30 \mathrm{keV} \mathrm{Bi}_{3}{ }^{+}$primary beam with a current $0.55 \mathrm{pA}$. The analyzed area used in this work is a square of $200 \mu \mathrm{m} \times 200 \mu \mathrm{m}$. Negative ion spectra were internally calibrated using $\mathrm{H}^{-}, \mathrm{C}^{-}$, $\mathrm{C}_{2}{ }^{-}, \mathrm{C}_{3}{ }^{-}$and $\mathrm{C}_{4}{ }^{-}$peaks normalized to the respective secondary total ion yields. The depth profile is a square of $500 \mu \mathrm{m} \times 500$ 
$\mu \mathrm{m}$ using $\mathrm{Ar}_{n}{ }^{+}$, with $n=\sim 1000$ atoms as sputter argon gas cluster ion particles at $2.5 \mathrm{keV}$. Furthermore, the work function (WF) was obtained with a Kelvin probe system (KP 6500 Digital Kelvin Probe). The surface chemical composition of the CzxN/ ITO layer was investigated by an X-ray photoelectron spectrometer (XPS) model Theta Probe AR-XPS System (Thermo Fisher Scientific, U.K) in the KBSI Busan Center. The X-ray source was Al $\mathrm{K} \alpha(1486.6 \mathrm{eV})$, operating at $100 \mathrm{~W}$. The XPS spectra were curve fitted with a mixed Gaussian-Lorentzian shape and Shirley background using the analysis software XPSPEAK 4.1.

\section{Conflicts of interest}

There are no conflicts to declare.

\section{Acknowledgements}

This research was supported by the Technology Development Program to Solve Climate Changes of the National Research Foundation (NRF) funded by the Ministry of Science, ICT \& Future Planning (NRF-2015M1A2A2057510). H. K. acknowledges the financial support from the National Foundation of Korea (NRF) grant funded by the Korea Government (the Ministry of Science and ICT, MSIT) (NRF-2017R1A2B4012490). Also, this work was supported by a GIST Research Institute (GRI) grant funded by GIST in 2018.

\section{References}

1 R. Søndergaard, M. Hösel, D. Angmo, T. T. Larsen-Olsen and F. C. Krebs, Mater. Today, 2012, 15, 36-49.

2 W. Liu, S. Liu, N. K. Zawacka, T. R. Andersen, P. Cheng, L. Fu, M. Chen, W. Fu, E. Bundgaard, M. Jørgensen, X. Zhan, F. C. Krebs and H. Chen, J. Mater. Chem. A, 2014, 2, 1980919814.

3 S. Khan, L. Lorenzelli and R. S. Dahiya, IEEE Sens. J., 2015, 15, 3164-3185.

4 Y.-W. Su, S.-C. Lan and K.-H. Wei, Mater. Today, 2012, 15, 554-562.

5 P. M. Beaujuge and J. M. J. Frechet, J. Am. Chem. Soc., 2011, 133, 20009-20029.

6 H. Yao, L. Ye, H. Zhang, S. Li, S. Zhang and J. Hou, Chem. Rev., 2016, 116, 7397-7457.

7 Y. Li, Acc. Chem. Res., 2012, 45, 723-733.

8 M. Tanveer, A. Habi and M. B. Khan, NUSTJ. eng. sci., 2013, 6, 15-20.

9 H.-C. Liao, C.-C. Ho, C.-Y. Chang, M.-H. Jao, S. B. Darling and W.-F. Su, Mater. Today, 2013, 16, 326-336.

10 F. Zhao, C. Wang and X. Zhan, Adv. Energy Mater., 2018, 1703147.

11 Y. Liu, J. Zhao, Z. Li, C. Mu, W. Ma, H. Hu, K. Jiang, H. Lin, H. Ade and H. Yan, Nat. Commun., 2014, 5, 5293.

12 J. Xiong, B. Yang, C. Cao, R. Wu, Y. Huang, J. Sun, J. Zhang, C. Liu, S. Tao, Y. Gao and J. Yang, Org. Electron., 2016, 30, 3035.
13 S. Nam, J. Seo, S. Woo, W. H. Kim, H. Kim, D. D. C. Bradley and Y. Kim, Nat. Commun., 2015, 6, 8929.

14 Y.-J. Noh, S.-I. Na and S.-S. Kim, Sol. Energy Mater. Sol. Cells, 2013, 117, 139-144.

15 H.-C. Chen, S.-W. Lin, J.-M. Jiang, Y.-W. Su and K.-H. Wei, ACS Appl. Mater. Interfaces, 2015, 7, 6273-6281.

16 H.-K. Lin, Y.-W. Su, H.-C. Chen, Y.-J. Huang and K.-H. Wei, ACS Appl. Mater. Interfaces, 2016, 8, 24603-24611.

17 C. V. Hoven, A. Garcia, G. C. Bazan and T.-Q. Nguyen, Adv. Mater., 2008, 20, 3793-3810.

18 Y. Sun, J. H. Seo, C. J. Takacs, J. Seifter and A. J. Heeger, Adv. Mater., 2011, 23, 1679-1683.

19 A. Guerrero, S. Chambon, L. Hirsch and G. Garcia-Belmonte, Adv. Funct. Mater., 2014, 24, 6234-6240.

20 J. Kong, J. Lee, Y. Jeong, M. Kim, S.-O. Kang and K. Lee, Appl. Phys. Lett., 2012, 100, 213305.

21 X. Bulliard, S. Ihn, S. Yun, Y. Kim, D. Choi, J. Choi, M. Kim, M. Sim, J. Park, W. Choi and K. Cho, Adv. Funct. Mater., 2010, 20, 4381-4387.

22 W. Beek, M. Wienk, M. Kemerink, X. Yang and R. Janssen, J. Phys. Chem. B, 2005, 109, 9505-9516.

23 S. Dkhil, D. Duché, M. Gaceur, A. Thakur, F. Aboura, L. Escoubas, J. Simon, A. Guerrero, J. Bisquert, G. Belmonte, Q. Bao, M. Fahlman, C. Ackermann, O. Margeat and J. Ackermann, Adv. Energy Mater., 2014, 4, 1400805-1400816.

24 Z. He, C. Zhong, S. Su, M. Xu, H. Wu and Y. Cao, Nat. Photonics, 2012, 6, 591-595.

25 Y. Zhou, C. Fuentes-Hernandez, J. Shim, J. Meyer, A. J. Giordano, H. Li, P. Winget, T. Papadopoulos, H. Cheun, J. Kim, M. Fenoll, A. Dindar, W. Haske, E. Najafabadi, T. M. Khan, H. Sojoudi, S. Barlow, S. Graham, J.-L. Brédas, S. R. Marder, A. Kahn and B. A. Kippelen, Science, 2012, 336, 327-332.

26 M. Song, J.-W. Kang, D.-H. Kim, J.-D. Kwon, S.-G. Park, S. Nam, S. Jo, S. Y. Ryu and C. S. Kim, Appl. Phys. Lett., 2013, 102, 143303.

27 D. Ma, M. Lv, M. Lei, J. Zhu, H. Wang and X. Chen, ACS Nano, 2014, 8, 1601-1608.

28 J. Wang, K. Lin, K. Zhang, X.-F. Jiang, K. Mahmood, L. Ying, F. Huang and Y. Cao, Adv. Energy Mater., 2016, 6, 1502563.

29 J. Lee, H. Kang, S. Kee, S. H. Lee, S. Y. Jeong, G. Kim, J. Kim, S. Hong, H. Back and K. Lee, ACS Appl. Mater. Interfaces, 2016, 8, 6144-6151.

30 Z. Li, Y. Liu, K. Zhang, Z. Wang, P. Huang, D. Li, Y. Zhou and B. Song, Langmuir, 2017, 33, 8679-8685.

31 H. Zhao, Y. Luo, L. Liu, Z. Xie and Y. Ma, Mater. Chem. Front., 2017, 1, 1087-1092.

32 Y.-M. Chang, R. Zhu, E. Richard, C.-C. Chen, G. Li and Y. Yang, Adv. Funct. Mater., 2012, 22, 3284-3289.

33 S. Dong, Z. Hu, K. Zhang, Q. Yin, X. Jiang, F. Huang and Y. Cao, Adv. Mater., 2017, 29, 1701507.

34 T. Schmaltz, G. Sforazzini, T. Reichert and H. Frauenrath, Adv. Mater., 2017, 29, 1605286.

35 J. Vinokur, B. Shamieh, I. Deckman, A. Singhal and G. L. Frey, Chem. Mater., 2016, 28, 8851-8870. 
36 J. Lee, J. Kim, C.-L. Lee, G. Kim, T. K. Kim, H. Back, S. Jung, K. Yu, S. Hong, S. Lee, S. Kim, S. Jeong, H. Kang and K. Lee, Adv. Energy Mater., 2017, 7, 1700226.

37 H. Kang, J. Lee, S. Jung, K. Yu, S. Kwon, S. Hong, S. Kee, S. Lee, D. Kim and K. Lee, Nanoscale, 2013, 5, 11587-11591.

38 H. Kang, S. Kee, K. Yu, J. Lee, G. Kim, J. Kim, J.-R. Kim, J. Kong and K. Lee, Adv. Mater., 2015, 27, 1408-1413.

39 H. Kang, S. Hong, J. Lee and K. Lee, Adv. Mater., 2012, 24, 3005-3009.

40 S. Kim, H. Kang, S. Hong, J. Lee, S. Lee, B. Park, J. Kim and K. Lee, Adv. Funct. Mater., 2016, 26, 3563-3569.

41 Z. Gao, Y. Zheng, Z. Wang and J. Yu, J. Lumin., 2018, 201, 359-363.

42 F.-C. Wu, K.-C. Tung, W.-Y. Chou, F.-C. Tang and H.-L. Cheng, Org. Electron., 2016, 29, 120-126.

43 L. Qiu, L. K. Ono, Y. Jiang, M. R. Leyden, S. R. Raga, S. Wang and Y. Qi, J. Phys. Chem. B, 2018, 122, 511-520.

44 W. Lee, S. Jeong, C. Lee, G. Han, C. Cho, J.-Y. Lee and B. J. Kim, Adv. Energy Mater., 2017, 7, 1602812.
45 Z. Wu, C. Sun, S. Dong, X. F. Jiang, S. Wu, H. Wu, H. L. Yip, F. Huang and Y. Cao, J. Am. Chem. Soc., 2016, 138, 20042013.

46 A. Misra, P. Kumar, R. Srivastava, S. K. Dhawan, M. N. Kamalasanan and S. Chandra, Indian J. Pure Appl. Phys., 2005, 43, 921-925.

47 R. Heuvel, J. J. Franeker and R. A. J. Janssen, Macromol. Chem. Phys., 2017, 218, 1600502.

48 J. F. Moulder, W. F. Strickle, P. E. Sobol and K. D. Bomben, Handbook of X-Ray Photoelectron Spectroscopy, Perkin-Elmer, Eden Prairie, MN, 1992.

49 K. H. Lee, H. W. Jang, K.-B. Kim, Y.-H. Tak and J.-L. Lee, J. Appl. Phys., 2004, 95, 586-590.

$50 \mathrm{H}$. Estrade-Szwarckopf, B. Rousseau, C. Herold and P. Lagrange, Mol. Cryst. Liq. Cryst., 1998, 310, 231-236.

51 K.-W. Tsai, S.-N. Hsieh, T.-F. Guo, Y.-J. Hsu, A. K.-Y. Jene and T.-C. J. Wen, J. Mater. Chem. C, 2013, 1, 531-535. 